\title{
The earliest known venomous animals recognized among conodonts
}

\author{
Hubert Szaniawski \\ Acta Palaeontologica Polonica 54 (4), 2009: 669-676 doi: http://dx.doi.org/10.4202/app.2009.0045
}

Conodonts, a large group of tiny extinct marine animals ranging in age from the Late Cambrian to Late Triassic (ca. 500 to $200 \mathrm{Mya}$ ), are usually considered as jawless vertebrates. Their only commonly occurring fossilized remains are minute, phosphatic, teeth-like elements of their feeding apparatuses. In most of the early conodonts the elements were conical and strongly elongated. Many of them are characterized by possession of a deep, longitudinal groove, usually associated with sharp edges or ridges. A comparative study of the grooved elements and venomous teeth and spines of living and extinct vertebrates strongly suggests that the groove in conodonts was also used for delivery of venom. Structural convergence of elements of the conodont apparatus with the grasping apparatus of chaetognaths, a group of extant, venomous, invertebrate predators of similarly ancient origin, provides additional support for this conclusion.

Key words: Vertebrata, Conodonta, venomous animals.

Hubert Szaniawski [szaniaw@twarda.pan.pl]. Instytut Paleobiologii PAN, ul. Twarda 51/55, PL-00-818 Warszawa, Poland

This is an open-access article distributed under the terms of the Creative Commons Attribution License (for details please see creativecommons.org), which permits unrestricted use, distribution, and reproduction in any medium, provided the original author and source are credited. 